\title{
Profile of apheresis donors at Professor Alberto Antunes University Hospital of the Federal University of Alagoas
}

\author{
Perfil de doadores de aférese no Hospital Universitário Professor Alberto \\ Antunes da Universidade Federal de Alagoas
}

Laís Pereira Leite de Araújo Loureiro ${ }^{1}$ (D) , Sthephanie de Lima Zielak ${ }^{1}$ (D) Ingryd Leylane de Holanda Galvão Almeida² (D), Kledson Lopes Barbosa² (D), Cinthya Pereira Leite Costa de Araújo1,2 (D)

\begin{abstract}
Hemotherapy services play a key role in attracting donors and providing safe blood to the population. The apheresis platelet collection procedure is a relatively simple, safe and important procedure for increasing the stocks of these services. However, the recruitment and retention of these donors still represent a major challenge. Objective: Evaluating the profile of donors of blood components by apheresis in the Transfusion Unit of Professor Alberto Antunes University Hospital - UFAL, as well as knowing the hematological parameters pre- and post-donation, the occurrence of the main adverse events related to the procedure and the difficulties faced by the donor. Method: This was a cross-sectional observational study. We analyzed a total of 160 forms of apheresis donors from March 2017 to June 2018. The data were tabulated using the Excel program, and then analyzed in order to determine the objectives. Results: Most donors were male (93.13\%), aged between 25 and 40 years (48.75\%) and brown $(25.62 \%)$. There was a slight prevalence of singles $(49.37 \%)$ and $73.75 \%$ were from Maceió. The most prevalent $\mathrm{ABO}$ and Rh phenotyping was $\mathrm{O}+(39.3 \%)$. Most of the procedures were simple platelet collection (75.60\%) and the occurrence of adverse events during donations was $30.63 \%$. Conclusion: Evaluation of apheresis donor profile and the knowledge of the possible side effects related to the procedure provided a better understanding of this type of donation and may improve the capture and retention processes of these individuals, minimizing the effects of lack of blood for Alagoana population.
\end{abstract}

Keywords: Therapeutic apheresis, Apheresis supply, Apheresis for donation, Transfusion reaction, Adverse events in the apheresis donations.

\begin{abstract}
RESUMO
Os serviços de hemoterapia desempenham um papel fundamental na atração de doadores e no fornecimento de sangue seguro à população. No entanto, o recrutamento e a retenção desses doadores ainda representam um grande desafio. Objetivo: Avaliar o perfil dos doadores de hemocomponentes por aférese na Unidade de Transfusão do Hospital Universitário Professor Alberto Antunes - UFAL, bem como conhecer os parâmetros hematológicos pré e pós-doação, a ocorrência dos principais eventos adversos relacionados à procedimento e as dificuldades enfrentadas pelo doador. Método: Estudo observacional transversal. Foram analisadas 160 fichas de doadores de aférese de março de 2017 a junho de 2018. Os dados foram tabulados no programa Excel e analisados para determinar os objetivos. Resultados: A maioria dos doadores era do sexo masculino (93,13\%), com idade entre 25 e 40 anos $(48,75 \%)$ e parda $(25,62 \%)$. Houve uma leve prevalência de solteiros $(49,37 \%)$ e $73,75 \%$ eram de Maceió. A fenotipagem $\mathrm{ABO}$ e $\mathrm{Rh}$ mais prevalente foi $\mathrm{O}+(39,3 \%)$. A maioria dos procedimentos foi de coleta simples de plaquetas $(75,60 \%)$ e a ocorrência de eventos adversos durante as doações foi de $30,63 \%$. Conclusão: A avaliação do perfil do doador de aférese e o conhecimento dos possíveis efeitos colaterais relacionados ao procedimento proporcionaram uma melhor compreensão sobre esse tipo de doação e podem ajudar a melhorar os processos de captura e retenção desses indivíduos, minimizando os efeitos da falta de sangue para a população Alagoana.
\end{abstract}

Palavras-chave: Aférese terapêutica, Suprimento de aférese, Aférese para doação, Reação de transfusão, Eventos adversos nas doações de aférese.

1 UNIT - Centro Universitário Tiradentes, Maceió, AL, Brazil

2 Professor Alberto Antunes University Hospital, Maceió, AL, Brazil 


\section{INTRODUCTION}

Maintaining blood component stocks is one of the biggest challenges for hemotherapy services in the world. Awareness of the population about the importance of blood donation is one of the central pillars of actions to capture donors to meet daily demands and emergency ${ }^{1,2}$.

Apheresis blood collection allows for a selective and multi-component donation from a single donor in greater quantity and quality than a whole blood donation, with lower antigen exposure and risk of disease transmission to recipients. Despite its importance, apheresis is still poorly known by most blood donors and health professionals, especially in public services in the North and Northeast of Brazill,3.

The word apheresis, from the Greek "separate", is the selective process of collecting blood from a single donor or patient through automated separation of its components due to different densities, retention of the blood component to be collected, and return of the remainder to the donor / patient. The collection of blood components by apheresis may be performed for transfusion purposes, from the collection of blood components from a donor, or therapy, where there is the removal of cells or plasma from patients related to the development of pathologies, and their substitution by replacement fluids or healthy cells for treatment purposes ${ }^{1,3}$

In the face of so many studies and innovations in hematology and hemotherapy, apheresis donation has been widely used in transfusion medicine, and in the treatment of various diseases. This method emerged in the early twentieth century, but only in the 1970s equipment capable of safely performing the procedure and on a large scale was developed, allowing its wide use. In Alagoas, the first apheresis collection was held in 1997 at the Hemotherapy Service of Santa Casa de Misericórdia de Maceió, beginning a new era in hemotherapy in the state. Currently, in Brazil, there are already several specialized apheresis centers ${ }^{2,4}$.

In transfusion apheresis, donor selection should follow the same criteria as for whole blood donors, but there are some specificities and specific criteria to each type of donation, as well as different timeframes and intervals between collections ${ }^{5}$. The donor must agree to the procedure by signing a free and informed consent form, which should clearly explain all the collection steps and their possible complications and risks. Throughout the procedure, the donor should be accompanied by the responsible team, under the supervision of the blood therapist and with access to emergency care to respond to possible more serious adverse reactions ${ }^{5}$.

Donors should undergo the same laboratory tests as the whole blood donor, as well as specific tests for each type of donation. Laboratory screening for transmissible blood infections must always be performed on a sample taken on the same day as the procedure, thus ensuring the quality of the donated blood component and transfusion safety ${ }^{5}$. In addition to the evaluation that is already performed on any blood donor candidate, apheresis donors need to be carefully judged with regard to venous access, blood volume, and platelet counts. It is important to point out that those with a history of use of medications that interfere with platelet function for 7 days will be temporarily excluded ${ }^{6,8}$.

Some studies show that, in relation to the profile of apheresis donors in Brazil, most are male and the most frequent age range is 30 to 40 years, followed by 19 to 29 years. The incidence is much lower in donors aged $>60$ years. The predominant ethnicity is caucasian and married marital status predominates when compared to single and divorced. The most prevalent blood type is $\mathrm{O}+$, as in the world population, and most donors' schooling is High School. It is also observed that most donors make only 1 donation within 12 months. The average platelet count mostly ranges from 201.000 to $250.000 / \mathrm{mm}^{3} 3,9,10$.

Plateletpheresis for transfusion purposes is the most commonly performed apheresis procedure in the world. The lack of iron loss, due to the absence of red blood cells loss during collection, allows apheresis donations to be made at smaller intervals than whole blood donations, resulting in a greater number of single donor donations over time, minimizing the lack of this blood component to patients ${ }^{11}$.

The amount of platelets in each unit collected by apheresis is exponentially higher than that 
obtained by conventional donation. Thus, from a single platelet donation by apheresis, it is possible to provide a complete transfusion dose for an adult patient, while 6 to 8 platelet units obtained through whole blood donation would be required to get the same dose, that is, 6 to 8 donors ${ }^{4,11,12}$.

Depending on the type of apheresis equipment and the anthropometric and hematological characteristics of the donor, multiple components can be collected from a single donor in the same procedure, combined according to the stocking needs of the hemotherapy service. Thus, for example, a concentration of platelets and a concentration of red blood cells may be collected; two concentrations of platelets or two concentrations of red blood cells, allowing better use of the donor's participation in the service and meeting stock needs ${ }^{10,13}$.

The frequency of adverse events in this type of donation is low and may occur in 5 to $17 \%$ of apheresis procedures, being more common in mostly mild therapeutic procedures, requiring no interruption of collection. Adverse events are mainly associated with venous access (bruising, infections or other vascular complications), hypocalcemia related to the presence of sodium citrate anticoagulant (perioral paraesthesia, labial tingling, arrhythmia, extrasystoles), vaso-vagal reaction, extracorporeal volume and environmental factors ${ }^{13,15}$.

Careful selection of donors and follow-up of the procedure are essential for minimizing the risk of complications and an important factor for recruiting new donors, as it is essential to ensure their safety and retention. Obtaining data on the incidence of these events enables dynamic review with the medical and nursing teams to improve donor safety and comfort, minimize underreporting of these events, and discuss and create a national hemovigilance system for an adverse event in apheresis donations $s^{8,11,15}$.

It is essential that multidisciplinary teams, which directly accompany donors in the Brazilian hemotherapy services, are well trained to identify and treat these complications, as well as to know how to guide apheresis donors during the procedure, and to make them aware of the possibility of the appearance of these adverse events during collection ${ }^{3}$.
Blood collection by apheresis is responsible for increasing the number of blood components collected from a single donor, representing an important mechanism for improving blood stocks for the population. Our research aimed to evaluate the profile of donors and blood collection by apheresis of the Transfusion Unit of Professor Alberto Antunes University Hospital/UFAL/EBSERH, besides knowing the main adverse events related to the collection procedure and the difficulties faced by the donor, in order to outline strategies to improve the capture and retention of these donors, thus contributing to the maintenance of blood component stocks for the population.

\section{METHODS}

This is a cross-sectional observational study, conducted at the Transfusion Unit of Professor Alberto Antunes University Hospital, located in Maceió - Alagoas, from the date of approval of the project by the Research Ethics Committee (REC) of Centro Universitário Tiradentes. Inclusion criteria were donors able to donate components by apheresis, according to Ordinance 158 of the Ministry of Health of February 4th, 2016, who donated blood at the Transfusion Unit of Professor Alberto Antunes University Hospital from March 2017 to June 2018. All collections were performed on TRIMA ACCEL ${ }^{\circledR}$ transfusion apheresis equipment, manufactured by TERUMO BCT. Exclusion criteria were unfit donors, according to the norms referred to in Ordinance 158. Initially, data from 160 blood donor forms that fit the selected period were collected. The data were tabulated in the Excel program, and then analyzed in order to meet the proposed research objectives.

For this study, the waiver of the consent form was requested to REC, given the operational unfeasibility of calling donors. However, information such as name, address and telephone number of the subjects were not included, safeguarding their identification, maintaining the confidentiality of information, respecting the ethical criteria of nonmaleficence. The present study was approved by the Research Ethics Committee of Centro Universitário Tiradentes - UNIT/AL with the number 3.372.798. 


\section{RESULTS}

Of the 160 apheresis donors analyzed, 149 (93.13\%) were male donors and only $11(6.87 \%)$ were female. The most prevalent age group was between 25 and 40 years and mostly brown, as shown in Table 1.

Table 1 Donors by apheresis according to gender, age and ethnicity.

\begin{tabular}{lll}
\hline Gender & $\mathbf{n}$ & $\mathbf{\%}$ \\
\hline Male & 149 & $93.13 \%$ \\
Female & 11 & $6.87 \%$ \\
\hline Age & & \\
\hline $18-24$ years & 37 & $23.12 \%$ \\
$25-40$ years & 78 & $48.75 \%$ \\
$41-60$ years & 43 & $26.88 \%$ \\
$61-69$ & 2 & $1.25 \%$ \\
\hline Ethnicity & & \\
\hline White & 17 & $10.64 \%$ \\
Black & 16 & $10.00 \%$ \\
Brown & 41 & $25.62 \%$ \\
Indigenous & 1 & $0.62 \%$ \\
No data & 85 & $53.12 \%$ \\
\hline
\end{tabular}

Regarding marital status, a slight prevalence of single donors was evidenced and the origin from the city of Maceió prevailed (Table 2).

Table 2 Prevalence of apheresis donors according to marital status and origin.

\begin{tabular}{lll}
\hline Marital Status & $\mathbf{n}$ & \% \\
\hline Married & 68 & $42.50 \%$ \\
Single & 79 & $49.37 \%$ \\
Divorced & 5 & $3.12 \%$ \\
Widow & 1 & $0.62 \%$ \\
No data & 7 & $4.39 \%$ \\
Orgin & & \\
Maceió & 118 & $73.75 \%$ \\
Other cities in Alagoas & 40 & $25 \%$ \\
Other Brazilian states & 2 & $1.25 \%$ \\
\hline
\end{tabular}

In the analysis of education and profession, 85 donation forms (53.12\%) did not have information related to these data, and only 75 donors were included. There was higher incidence of donors who have finished High School (18.76\%) and we found only $8.75 \%$ of donors with complete higher education (Table 3). Most of the donors were mid-level professionals, corresponding to $38.13 \%$ of the individuals analyzed (Table 3 ).

Table 3 Prevalence of apheresis donors regarding education and professional profile.

\begin{tabular}{lll}
\hline Education & $\mathbf{n}$ & $\mathbf{\%}$ \\
\hline Illiterate & 1 & $0.62 \%$ \\
Elementary School & 10 & $6.25 \%$ \\
Complete Elementary School & 4 & $2.50 \%$ \\
Incomplete High School & 10 & $6.25 \%$ \\
Complete High School & 28 & $18.76 \%$ \\
Incomplete Higher Education & 6 & $3.75 \%$ \\
Undergraduate & 14 & $8.75 \%$ \\
No data & 85 & $53.12 \%$ \\
\hline Professional level & & \\
\hline Medium & 61 & $38.13 \%$ \\
High & 14 & $8.75 \%$ \\
No data & 85 & $53.12 \%$ \\
\hline
\end{tabular}

Of the 160 apheresis collections analyzed, $109(68.12 \%)$ were voluntary donations and 51 $(31.88 \%)$ were replacement donations, similar data regarding whole blood donations made at the Professor Alberto Antunes University Hospital Hemotherapy Service. In relation to the type of capture performed, it was found that most donors (26.25\%) voluntarily went to the Professor Alberto Antunes University Hospital Hemotherapy Service for whole blood donation, but the apheresis donation was captured; $12.5 \%$ because friends asked them to; $8.13 \%$ of family members and $53.12 \%$ of the forms did not contain data related to the type of capture performed.

Anthropometric data from the clinical pre-screening (weight, height and temperature) and the hematological profile of the pre-donation donors (hemoglobin and platelet count) were analyzed according to the average values. All the aphe- 
resis donor suitability criteria were met according to Ministerial Ordinance ${ }^{5}$, as shown in Table 4.

Table 4 Anthropometric data and pre-donation hematological profile of blood donors by apheresis.

\begin{tabular}{ll}
\hline Clinical pre-screening & Average \\
\hline Weight & $82.76 \mathrm{~kg}$ \\
Height & $1.72 \mathrm{~m}$ \\
Temperature & $36.0^{\circ} \mathrm{C}$ \\
\hline Hematological Profile & \\
\hline Hematocrit & $45 \%$ \\
Red blood cells & $15 \mathrm{~g} / \mathrm{dL}$ \\
Platelets & $235.419 \mathrm{~mm}^{3}$ \\
\hline
\end{tabular}

Regarding the phenotyping of the $A B O$ and Rh (Rhesus Antigen) Systems, the majority of donors were $\mathrm{O}+(39.38 \%)$, followed by $\mathrm{A}+$ $(31.25 \%)$ and $B+(10.63 \%)$. The negative blood types were the smaller percentage (Table 5 ).

Table 5 Donor apheresis distribution by $A B O$ and $R h$ phenotyping.

\begin{tabular}{lll}
\hline Blood typing & $\mathbf{n}$ & \% \\
\hline O+ & 63 & 39.38 \\
O- & 13 & 8.12 \\
A+ & 50 & 31.25 \\
A- & 8 & 5 \\
B+ & 17 & 10.63 \\
B- & 0 & 0 \\
AB+ & 5 & 3.12 \\
AB- & 0 & 0 \\
No data & 4 & 2.50 \\
Total & 160 & 100 \\
\hline
\end{tabular}

The characteristics of the units collected and the donor hematological data after donation revealed that the average volume of platelet concentrates was $260 \mathrm{~mL}$ for single collections (1 unit) and $468 \mathrm{~mL}$ for double collections. The average platelet yield, which corresponds to the platelet count per unit, was $3.16 \times 10^{11}$ for single collections and $6.27 \times 10^{11}$ for double collections (Table 6).
The average hematocrit and donor platelet count provided by the apheresis equipment after the procedure is complete are shown in Table 6, which is in accordance with the mandatory quality control requirements in Brazil ${ }^{5}$.

Table 6 Average platelet volume and yield of the units collected and hematological data after donation.

\begin{tabular}{ll}
\hline After donation data & Média \\
\hline Volume Single Collections & $260.0 \mathrm{~mL}$ \\
Volume Double Collections & $468.0 \mathrm{~mL}$ \\
Platelet Yield Single Collections & $3.16 \times 10^{11}$ \\
Platelet Yield Double Collections & $6.27 \times 10^{11}$ \\
Platelet After & $173.667 \mathrm{~mm}^{3}$ \\
Hematocrit After & $43 \%$ \\
\hline
\end{tabular}

The results reported that from the total of 160 donations, the majority, 108 (67.50\%), corresponded to the single collection of platelets and 52 collections ( $32.5 \%)$ were multiple blood component collection (double platelet and platelet and red blood cell), according to table 7 .

Table 7 Simple and Multiple Component Apheresis Collection Procedures.

\begin{tabular}{lll}
\hline Type of Collection & $\mathbf{n}$ & \% \\
\hline $\begin{array}{l}\text { Single (01 unit of platelet) } \\
\begin{array}{l}\text { Double (02 units of pla- } \\
\text { telet) }\end{array}\end{array}$ & 108 & $67.50 \%$ \\
$\begin{array}{l}\text { Double blood component } \\
\text { (platelet red blood cell) }\end{array}$ & 13 & $8.13 \%$ \\
& & \\
Total & 160 & $100.00 \%$ \\
\hline
\end{tabular}

Adverse events happened in $30.63 \%$ of the collections performed, but the interruption of the procedure was required in only $18.12 \%$. Of the 160 donors, 49 reported adverse events and only 7 reported more than one event in the same collection. Of the 60 events found, most were mild and related to the sodium citrate anticoagulant used during the procedure: 19 labial tingling 
episodes $(31.7 \%), 18$ puncture site hematomas $(30 \%), 6$ vaso-vagal reactions $(10 \%), 3$ cases of hypotension ( $5 \%), 2$ tachycardias $(3.3 \%), 1$ dizziness $(1.7 \%)$ and 11 episodes of nonspecific reactions (18.3\%).

Regarding the difficulties related to the donation of blood components by apheresis, it was found that $17(10.67 \%)$ donors reported some type of difficulty, one case of insomnia after collection and the other 16 were related to the "fear" of the procedure, as: anxiety, nervousness and anguish. Despite the reported difficulties and side effects found, $45 \%$ of donors stated that they would return to apheresis collection, unfortunately $53.12 \%$ of donation forms did not contain this information.

\section{DISCUSSION}

The constant lack of blood components in Brazil's hemotherapy services represents a major public health problem in our country. Blood collection by apheresis is responsible for the increase in the number of blood components collected from a single donor, associated with an improvement in the final quality of the product, which represents an important mechanism for reducing the lack of blood for patients who need it ${ }^{1,2}$. Professor Alberto Antunes University Hospital/ UFAL / EBSERH is a reference for the treatment of cancer patients in the state of Alagoas, being this type of patient the largest group of blood components users in transfusion practice. Therefore, it requires continuous measurements of donor capture, thus enabling treatment and prevention of disease-related complications. The evaluation of the blood donor profile by apheresis of Professor Alberto Antunes University Hospital Transfusion Unit, as well as the knowledge of the possible side effects related to the procedure, may help to improve the capture and retention processes of these individuals, thus minimizing the effects of lack of blood to the population of our state.

The apheresis platelet donors of Professor Alberto Antunes University Hospital Transfusion Unit / UFAL / EBSERH are mostly male, aged 25 to 40 years, brown, single and coming from the capital Maceió. The predominant education level was of donors with only complete High School compared to higher education and professionals of high school level. Professor Alberto Antunes University Hospital is a federal public hospital that provides lower socioeconomic level population, users of Unified Public Health System (SUS), with public health service, which justifies the found donor profile. Our predominance of single donors can be explained by the higher number of young people compared to the literature. These data are similar to other studies and demonstrate the need for more effective capture campaigns within female donors from the interior of the state ${ }^{9,11}$. However, a study on comparative demographic motivations and donation between plasma/platelets and whole blood donors ${ }^{16}$. The authors demonstrated that women were significantly more prevalent (58\%) for whole blood donation. In addition, it was found that the age ranges for whole blood and plasma/ platelet donation were similar, where $25 \%$ were between 18 and 29 years old, $22 \%$ belonged to the 30 -year category and $19 \%$ to 39 years old. Moreover, it was observed that $1 / 4$ of the subjects belonged to the 40 to 49 years category, and $1 / 3$ corresponded to the 50 to 56 years category.

The clinical and hematological evaluation of the donor before and after donation, as well as the volume and platelet characteristics of the blood component collected by apheresis, strictly followed the requirements that regulate the hemotherapy services in $\mathrm{Brazil}^{5}$ demonstrating the safety of the procedure and the final quality of the product ${ }^{11,13}$.

The most found blood type was $\mathrm{O}+$ followed by $A+$, which agrees with the distribution data in the world population and in agreement with data from other hemotherapy services in the country. Single plateletpheresis represented most collection procedures, with a lower incidence of double blood component collection. The small amount of double collections (red blood cells and platelets) was because the collection of red blood cells concentration by apheresis is recommended by the protocol of Professor Alberto Antunes University Hospital Transfusion Unit only for rare blood types, as well as the increase of the interval for future donations of platelet concentration ${ }^{1,3,15}$.

The occurrence of adverse events was $30.67 \%$. The most frequent one was the labial 
tingling due to hypocalcemia, related to the citrate anticoagulant used during the procedure, but the need for interruption of the collection was reported by only $18.2 \%$ of donors, demonstrating the safety of the procedure. We found a higher incidence of total puncture site events and bruises, compared to 4.4 to $17 \%$ described in the literature, which reinforces the initial inexperience of the medical and nursing teams responsible for the collection and the need for greater surveillance and periodic training of all involved to minimize the occurrence and severity of these adverse events ${ }^{3,17}$. An inspiring study on adverse reactions in blood donors and apheresis in Italian transfusion centers reported that in 2.641 plateletpheresis donations, there was a frequency of $0.68 \%$ $(18 / 2,641)$ of recorded vaso-vagal reactions ${ }^{18}$. The authors also reported that citrate toxicity occurred at a frequency of $0.38 \%(189 / 50.072)$ for all apheresis donations (plasmapheresis, plateletpheresis, and multicomponent donation). These data show the importance of early identification of these events by the health professionals who follow the collection, in order to establish a safe conduct for these complications and the need for no interruption of the procedure.

The prevalence of voluntary apheresis donations of blood components $(68.12 \%$ of donors), associated with the presence of $26.25 \%$ of donors who sought Professor Alberto Antunes University Hospital Transfusion Unit for whole blood donation but were redirected by the TEAM for blood collection by apheresis, and the "fear" of donation reported by $10.67 \%$ of donors, draws attention to the lack, in our work, of a social service professional and a structured program of donor capture and permanent education with information campaigns for the population of users of our services and health professionals, emphasizing the safety of the procedure and greater efficiency in relation to the donation of whole blood $^{1,4,8}$. It is worth mentioning the lack of data related to apheresis donors, due to the incorrect filling of the forms, which could be observed in up to $53.12 \%$ of the medical records, pointing to the need for adequate training to those responsible for this function.

\section{CONCLUSION}

The apheresis donor profile of the Professor Alberto Antunes University Hospital Transfusion Unit consists mostly of men, aged 25 to 40 years, brown, single, with complete high school education, living in Maceió, who have a medium-level profession and type $\mathrm{O}+$ blood. Regarding pre- and post-donation hematological parameters, we observed an average hematocrit of $45 \%$ and $43 \%$, and platelet count of $235.419 \mathrm{~mm}^{3}$ and $173.000 / \mathrm{mm}^{3}$, respectively. Despite the greater security of the apheresis procedure in relation to whole blood collection, we observed a frequency of $30.63 \%$ of adverse events, higher than reported in the literature, probably related to the initial implementation of this collection modality in our service. This study provided a better understanding of the act of apheresis donation and the importance of awareness of voluntary blood donation and its retention, as well as the possibility of sharing knowledge with the academic community. It is expected that these results can be applied in programs to improve donor capture, not only in the research hospital, but also in all transfusion units in the state, contributing to increase stocks and avoiding the lack of blood components for the population.

\section{REFERENCES}

1. Rodrigues RSM, Reibnitz KS. Estratégias de Captação de Doadores de Sangue: Uma Revisão Integrativa da Literatura. Texto \& Contexto Enferm. 2011;20(2):38491. Available from: https://doi.org/10.1590/S010407072011000200022

2. Cullought JM. Introduction to Apheresis Donations. Including History and General Principles in Apheresis: Principle and Pratice. USA; 1997.

3. Barbosa MH, da Silva KFN, Coelho DQ, Tavares JL, Da Cruz $\mathrm{LF}$, Kanda MH. Risk fatores associated with the occurrence of adverse events in plateletpheresis donation. Rev. Bras. Hematol. Hemoter. 2014;36(3):191-95. Available from: https://doi.org/10.1016/j.bjhh.2014.03.008

4. Teixeira RA. Contextualização da Captação de doadores na hemoterapia brasileira. In: Brasil, Ministério da Saúde. Manual de orientações para a promoção da doação voluntária de sangue. 1th ed, Brasília: Ministério da Saúde; 2015, p. 7-19. Available from: http://bvsms.saude.gov. br/bvs/publicacoes/manual_orientacoes_promocao_doacao_voluntaria_sangue.pdf 
5. Brasil Portaria no 158, de 04 de fevereiro de 2016, Seção 1, p 37 Redefine o regulamento técnico de procedimentos hemoterápicos. Publicada no Diário Oficial da União de no 25 05/02/2016; 2016.

6. Santis CG, Costa TD. Manual de medicina transfusional. Ubiali EA, editor, São Paulo: 2009.

7. Borges TS, Chaves JM, Vidigal DC. Cadernos Hemominas: assistência de enfermagem na coleta de sangue do doador e na hemotransfusão. Fundação Hemominas, Belo Horizonte, 2004.

8. Fundação Hemominas. Manual de normas e procedimentos de atendimento ao doador. Belo Horizonte (MG): Fundação Hemominas; 2012.

9. Ferreira O, Martinez EZ, Mota CA, Silva AM. Avaliação do conhecimento sobre hemoterapia. Rev. Bras. Hematol. Hemoter. 2007;29(2):160-67. Available from: https:// doi.org/10.1590/S1516-84842007000200015

10. Das SS, Chaudhary RK, Shukla JS. Factors influencing yield of plateletpheresis using intermitente flow cell separator. Clin Lab. Haematol. 2005;27(5):316-19. Available from: https://doi.org/10.1111/j.1365-2257.2005.00714.x

11. Brasil. Guia para o uso de Hemocomponentes. Brasília: Editora Saúde, 2014

12. Heal JM, Blumberg N. Optimazing platelet transfusion therapy. Blood Rev. 2004;18(3):149-65. Available from: https://doi.org/10.1016/S0268-960X(03)00057-2
13. Wollersheim J, Dautzenberg M, Griendt A, Sybesma B. Donor selection criteria to maximize double platelet products (DPP) by platelet apheresis. Transfus Apher Sci. $2006 ; 34(2): 179-86$. Available from: https://doi.or$\mathrm{g} / 10.1016 / \mathrm{j}$.transci.2005.12.004

14. Tomita T, Takayanagi M, Kiwada K, Mieda A, Takahashi C, Hata T. Vasovagal reactions in apheresis donors. Transfusion. 2002;42(12):1561-66. Available from: https:// doi.org/10.1046/j.1537-2995.2002.00241.x

15. Guo N, Wang J, Ness P, Yao F, Dong X, Bi X, et al. Demographics of apheresis platelet donors in five blood centers in China. Transfusion. 2012;52(3):560-66. Available from: https://doi.org/10.1111/j.1537-2995.2011.03328.x

16. Charbonneau J, Cloutier Marie-Soleil, Carrier É. Whole blood and apheresis donors in Quebec, Canada: Demographic differences and motivations to donate. Transfus. Apher. Sci. 2015;53(3):320-28. Availablefrom: https:// doi.org/10.1016/j.transci.2015.06.001

17. Morsing $\mathrm{KSH}$, Peters $\mathrm{AL}$, Van BJD, Vlaar APJ. The role of endothelium in the onset of antibody-mediated TRALI. Blood Rev. 2018;32(1):1-7. Available from: https://doi. org/10.1016/j.blre.2017.08.003

18. Croccos I, Franchini M, Garozzo G, Gandini AR. Adverse reactions in blood and apheresis donor: Experience from two Italian transfusion centers. Blood Transf. 2009; 7(1):35-8. Available from: https://dx.doi.or$\mathrm{g} / 10.2450 \% 2 \mathrm{~F} 2008.0018-08$ 
Corresponding Author:

Laís Pereira Leite de Araújo Loureiro

lais.plca@gmail.com

Editor:

Prof. Dr. Marcelo Riberto

Received in: apr 04, 2020

Approved in: jan 11, 2021

(c) (i) Este é um artigo publicado em acesso aberto (Open Access) sob a licença Creative

sem restrições, desde que o trabalho original seja corretamente citado. 